\title{
PROBLEM BASED LEARNING BERBANTUAN LEGO MENINGKATKAN PEMECAHAN MASALAH SISWA SEKOLAH DASAR
}

\author{
Zullya Ayu Malinda ${ }^{1}$, Murtono $^{2}$, dan Eka Zuliana ${ }^{3}$ \\ ${ }^{1,3}$ Prodi Pendidikan Guru Sekolah Dasar, Universitas Muria Kudus, Indonesia \\ ${ }^{2}$ Prodi Magister Pendidikan Dasar, Universitas Muria Kudus, Indonesia.
}

\section{Info Artikel}

Sejarah Artikel:

Diterima 19 Okt 2017

Disetujui 20 Nov 2017

Dipublikasikan Des 2017

\section{Keywords:}

Problem Base Learning,

Lego, Mathematics Problem Solving

\begin{abstract}
The purpose of classroom action research is to improve the students mathematic problem solving skills of grade IV SD 1 Kedungdowo through the problem based learning model assisted by lego. This research is a classroom action research with teacher research subject and 28 students. This study lasted for 2 cycles, each cycle consists of 4 stages of planning, action, observation and reflection. The independent variable in this research is lego assisted PBL. While the dependent variable in this research that is problem solving ability. Data collection techniques used is tests, observations, interviews and documentation. Data analysis used is quantitative and qualitative data analysis. The results showed that there was an increase of problem solving ability of mathematics in cycle I and Cycle II, that is from 70,92 (good) to 74,28 (good) with percentage of classical learning completeness equal to 64\% to 86\%. Supported by an increase in problem solving activity students score 2.51 (good) to 3.01 (good). In addition, teachers' skills in managing mathematics learning also increased by $74 \%$ (good) to $85 \%$ (very good).
\end{abstract}

\begin{abstract}
Abstrak
Tujuan penelitian tindakan kelas ini adalah meningkatkan kemampuan pemecahan masalah matematika siswa kelas IV SD 1 Kedungdowo menggunakan model problem based learning berbantuan lego. Penelitian ini merupakan penelitian tindakan kelas dengan subjek penelitian guru dan 28 siswa. Penelitian ini berlangsung selama 2 siklus, setiap siklus terdiri dari 4 tahap yaitu perencanaan, pelaksanaan, observasi dan refleksi. Variabel bebas pada penelitian ini adalah Model PBL berbantuan Lego. Sedangkan variabel terikat pada penelitian ini yakni kemampuan pemecahan masalah. Teknik pengumpulan data adalah tes, observasi, wawancara dan dokumentasi. Analisis data yang digunakan merupakan analisis data kuantitatif dan kualitatif. Hasil penelitian menunjukkan bahwa terdapat peningkatan kemampuan pemecahan masalah matematika pada siklus I dan Siklus II, yaitu dari 70,92 (baik) menjadi 74,28 (baik) dengan persentase ketuntasan belajar klasikal sebesar 64\% menjadi 86\%. Didukung dengan peningkatan aktivitas pemecahan masalah siswa memperoleh skor 2,51 (baik) menjadi 3,01 (baik). Selain itu, keterampilan guru mengelola pembelajaran matematika juga meningkat yaitu $74 \%$ (baik) menjadi $85 \%$ (sangat baik).
\end{abstract}

(C) 2017 Universitas Muria Kudus
p-ISSN 2087-9385 e-ISSN 2528-696X

\footnotetext{
Alamat korespondensi:

Program Studi Pendidikan Guru Sekolah Dasar

Fakultas Keguruan dan Ilmu Pendidikan Universitas Muria Kudus

Kampus UMK Gondangmanis, Bae Kudus Gd. L. 1t I PO. BOX 53

Kudus

Tlp (0291) 438229 ex.147 Fax. (0291) 437198

E-mail: uya.aylluz@gmail.com,murtono@umk.ac.id,

eka.zuliana@umk.ac.id
} 


\section{PENDAHULUAN}

Kemampuan dalam pembelajaran matematika di sekolah dasar seperti tercantum pada kurikulum 2006 terdiri dari kemahiran matematika dan diikuti dengan materi pembelajaran (Diknas, 2006). Kemahiran matematika mencakup kemampuan penalaran, kemampuan komunikasi, kemampuan pemecahan masalah, keterkaitan pengetahuan dan memiliki sikap menghargai kegunaan matematika.

Kemampuan pemecahan masalah menurut Anderson (2009) adalah keterampilan yang melibatkan proses menganalisis, menafsirkan, menalar, memprediksi, mengevaluasi, dan merefleksikan. Kemampuan pemecahan merupakan salah satu kemampuan yang perlu dikembangkan dalam matematika. Lencher dalam Wardhani (2010:37) mengatakan pemecahan masalah merupakan suatu keterampilan yang perlu diajarkan dan guru harus mengupayakannya melalui pembelajaran keterampilan memecahkan masalah yang mencakup empat langkah strategi pemecahan masalah. Polya (1973) memaparkan dalam pemecahan masalah memuat 4 langkah yaitu memahami masalah, merencanakan penyelesaian, melaksanakan rencana dan mengecek kembali.

Hasil survey TIMMS pada tahun 2016 mendudukkan Indonesia pada peringkat 44 dari 49 negara. Skor TIMMS yang diperoleh Indonesia yaitu domain pengetahuan (knowing) 395 dari skor rata-rata internasional 505, domain aplikasi (applying) sebanyak 397 dari rata-rata internasional 505 dan domain penalaran (reasoning) sebanyak 397 dari rata-rata internasional 504. Hasil domain konten matematika pada materi bilangan yaitu 399 dari rata-rata inernasional 506 (TIMMS 2015). Dari skor tersebut menunjukkan bahwa siswa Indonesia belum terbiasa dengan soal yang membutuhkan aspek tingkat tinggi seperti pada soal aplikasi dan penalaran.

Hal tersebut dibuktikan dengan hasil prasiklus terhadap siswa kelas IV SD 1 Kedungdowo yang berjumlah 28 siswa. Dengan KKM yang telah ditetapkan sekolah sebesar 65 terdapat sebanyak $96,42 \%$ siswa yang tidak tuntas dalam pencapaian hasil prasiklus kemampuan pemecahan masalah matematika dengan lingkup bilangan khususnya materi pecahan. Berbagai kesulitan siswa dalam memecahkan masalah sependapat dengan Ulya (2016) yang mengatakan bahwa antara lain penerapan rumus yang digunakan dalam menyelesaikan masalah.
Heruman (2016: 2) mengatakan pembelajaran matematika hendaknya melalui perbuatan dan pengertian, tidak hanya sekedar hafalan atau mengingat fakta saja, karena hal inu akan mudah dilupakan siswa. Piaget dalam Heruman (2016) mengatakan karakter siswa SD masih berada pada fase operasional konkrit dimana setiap konsep yang abstrak perlu segera diberi penguatan agar mengendap dan tahan lama dalam memori siswa.

Hal tersebut sejalan dengan Bruner yang mengatakan setiap konsep berkaitan dengan konsep yang lain sehingga siswa harus lebih banyak diberi kesempatan untuk melakukan keterkaitan yang di itandai dengan keaktifan siswa. Keaktifan siswa akan muncul jika guru memberikan persoalan kepada siswa agar mau mengembangkan pola pikir dan mengemukakan ide-ide. Winarni dan Harmini (2012: 114) mengatakan suatu cara pandang siswa tentang persoalan matematika ikut mempengaruhi pola pikir tentang penyelesaian masalah yang akan dilakukan.

Berdasarkan fakta yang telah dikemukakan dan karakteristik siswa SD maka upaya yang perlu dilakukan adalah dengan menerapkan model pembelajaran yang membantu siswa untuk lebih memahami proses pemecahan masalah. Arends (dalam Hosnan, 2014: 295) menyebutkan bahwa model problem based learning (PBL) adalah model pembelajaran dengan pendekatan pembelajaran siswa ppada masalah autentik sehingga siswa dapat menyusun pengetahuannya sendiri, menumbuhkembangkan keterampilan yang lebih tinggi dan inquiry.

PBL menjadikan masalah nyata sebagai pemicu dalam proses belajar sebelum mengetahui konsep formal. Siswa secara kritis mengidentifikasi informasi dan strategi yang relevan serta melakukan penyelidikan untuk menyelesaikan masalah tersebut. Dengan menyelesaikan masalah tersebut, siswa memperoleh pengetahuan serta mengembangkan kemampuan berpikir kritis dan kemampuan pemecahan masalah. Melalui proses diskusi pengetahuan tersebut terjalin menjadi pengetahuan siswa.

Tahapan-tahapan PBL yang dilaksanakan secara sistematis berpotensi untuk meningkatkan kemampuan pemecahan masalah sekaligus apat menguasai pengetahuan yang sesuai dengan kompetensi. Proses penyelesaian masalah tersebut dilaksanakan dalam 5 langkah yang dikemukakan Jihad dan Haris (2013) yaitu orientasi siswa terhadap masalah, mengorganisasikan siswa untuk belajar, melakukan penyelidikan individu dan kelompok, 
menyajikan hasil karya, menganalisis dan mengevaluasi proses pemecahan masalah.

Warsono (2013: 152) menyebutkan bahwa kelebihan dalam penerapan model PBL adalah siswa belajar dimulai dengan suatu masalah, kemudian siswa memperdalam pengetahuannya tentang apa yang telah mereka ketahui dan apa yang perlu mereka ketahui untuk memecahkan masalah, masalah yang dijadikan sebagai fokus pembelajaran dapat diselesaikan siswa melalui kerja kelompok sehingga dapat memberi pengalaman pada siswa seperti kerjasama dan interaksi dalam kelompok. Disamping itu pengalaman belajar yang berhubungan dengan pemecahan masalah seperti siswa membuat hipotesis, merancang percobaan melakukan penyelidikan, mengumpulkan data, menginterpretasikan data, membuat kesimpulan, mempresentasikan, berdiskusi dan membuat laporan. Kegiatan tersebut sangat diperlukan dalam menunjang proses pembelajaran.

Memahami teori tentang bagaimana orang belajar serta kemampuan menerapkannya dalam pengajaran matematika merupakan persyaratan penting untuk menciptakan proses pengajaran yang efektif. Pada teori belajar dienes ditekankan pada pembentukan konsep yang abstrak melalui permainan yang mengarah pada pembentukan konsep yang konkrit. Dengan demikian teori belajar dienes sangat cocok diterapkan pada pembelajaran matematika.

Dienes (dalam Runtukahu, 2014: 70) berpendapat bahwa pada dasarnya matematika dapat dianggap sebagai studi tentang struktur, memisah-misahkan hubungan-hubungan di antara struktur-struktur dan mengkategorikan hubungan-hubungan di antara struktur-struktur. Seperti halnya dengan bruner, dienes mengemukakan bahwa tiap-tiap konsep atau prinsip dalam matematika yang disajikan dalam bentuk yang konkret akan dapat dipahami dengan baik. Dalam penelitian ini, permainan lego digunakan untuk membantu siswa dalam mengkonkretkan sebuah masalah.

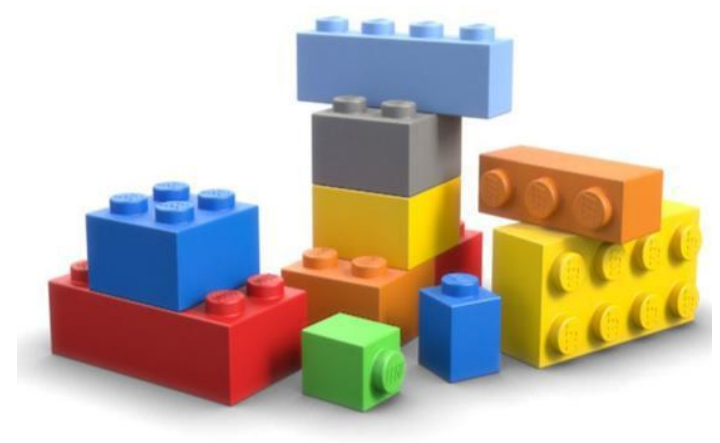

Gambar 1 Permainan Lego
Permainan lego sebagai media penunjang yang merangsang pemikiran anak untuk memecahkan suatu masalah matematika. Lego adalah sejenis alat permainan balok yang terbuat dari plastic kecil yang terkenal di dunia. Balokbalok ini serta kepingan lain bisa disusun menjadi model apa saja. Bermain bongkar pasang balok warna alias lego memang mengasyikkan.

Permainanini menyenangkan dan bisa meningkatkan kreativitas karena bermain membutuhkan imajinasi dan daya pikir pemainnya. Hal tersebut selaras dengan Penelitian Rejeki, dkk (2016) yang mengatakan bahwa lego dapat memunculkan kreativitas siswa dan membangun kerjasama, serta memfasilitasi guru untuk lebih berkonsentrasi pada proses pembelajaran.

Berdasarkan uraian tersebut, peneliti melaksanakan penelitian tindakan kelas dengan judul penerapan model pembelajaran problem based learning berbantuan permainan lego untuk meningkatkan kemampuan pemecahan masalah matematika materi pecahan siswa kelas IV SD 1 Kedungdowo.

\section{METODE PENELITIAN}

Penelitian ini merupakan penelitian tindakan kelas dengan model Kemmis dan Mc Taggart yang dilaksanakan di kelas IV SD 1 Kedungdowo yang terletak di Desa Kedungdowo Kecamatan Kaliwungu Kabupaten Kudus.

Subjek dalam penelitian ini adalah guru dan 28 siswa. Penelitian ini berlangsung selama 2 siklus, setiap siklus terdiri dari 4 tahap yaitu perencanaan, pelaksanaan, observasi dan refleksi.

Variabel bebas pada penelitian ini adalah penerapan model PBL berbantuan permainan lego. Sedangkan variabel terikat pada penelitian ini yakni kemampuan pemecahan masalah.

Teknik pengumpulan data menggunakan tes, observasi, wawancara dan dokumentasi. Untuk mendapatkan data yang akurat instrumen pengumpulan data yang digunakan yaitu pedoman wawancara guru, lembar observasi aktivitas kemampuan pemecahan masalah matematika siswa, lembar observasi keterampilan mengajar guru, soal tes evaluasi, dan foto kegiatan pembelajaran.

Sebelum diujikan soal tes evaluasi dilakukan uji validitas dan reliabilitas, kemudian hasil $r$ hitung dibandingkan dengan $r$ tabel sebesar 0,374 .

Teknik analisis data yang digunakan merupakan analisis data kualitatif dan kuantitatif. Data kuantitatif berupa nilai tes yang mengukur tingkat kemampuan pemecahan masalah 
matematika siswa. Untuk mengukur nilai tersebut digunakan pedoman penskoran tes kemampuan pemecahan masalah yang didasari oleh pendapat berikut.

Tabel 1 Pedoman Penskoran Tes Kemampuan Pemecahan Masalah

\begin{tabular}{clc}
\hline No & Indikator Pemecahan Masalah & Skor \\
\hline 1. & Memahami masalah & 3 \\
\hline 2. & Merencanakan pemecahan masalah & 2 \\
\hline 3. & Melaksanakan perhitungan & 3 \\
\hline 4. & Mengecek kembali & 2 \\
\hline \multicolumn{3}{c}{ Skor maksimal tiap butir soal } \\
\hline \multicolumn{3}{c}{ (dimodifikasi dari Hamzah 2014) }
\end{tabular}

Data kualitatif dalam penelitian ini diperoleh melalui lembar observasi yakni hasil observasi keterampilan mengajar guru serta aktiivitas pemecahan masalah matematika siswa selama proses pembelajaran matematika dengan menggunakan model Problem Based Learning berbantuan permainan lego. Sedangkan untuk menganalisis dan mensintesiskan data kualitatif tersebut dilakukan menggunakan teknik rating scale.

Indikator keberhasilan penelitian ini adalah sebagai berikut.

1. Keterampilan guru dalam mengelola pembelajaran menggunakan model pembelajaran Problem Based Learning berbantuan permainan lego sebesar $>70 \%$ dengan kriteria sekurang-kurangnya baik pada observasi.

2. Hasil rata-rata tes kemampuan pemecahan masalah siswa dalam pembelajaran manggunakan model pembelajaran Problem Based Learning berbantuan permainan lego sebesar $\geq 65$ dengan ketuntasan belajar klasikal $\geq 70 \%$.

3. Aktivitas pemecahan masalah matematika siswa menggunakan model pembelajaran Problem Based Learning berbantuan permainan lego sebesar >2,5 dengan kriteria sekurang-kurangnya baik pada observasi.

\section{HASIL DAN PEMBAHASAN}

Pada penelitian tindakan kelas ini, pembelajaran matematika yang dilakukan dikelas IV SD 1 Kedungdowo pada materi menyelesaikan masalah yang berkaitan dengan pecahan melalui model pembelajaran Problem Based Learning berbantuan permainan lego terdiri dari 5 tahap pembelajaran.

Tahap pertama yaitu orientasi siswa terhadap masalah. Langkah pemecahan masalah dalam tahap ini adalah memahami masalah. Diawali dengan guru membagikan lego kepaa siswa. Siswa diminta menyusun lego sesuai dengan kreasi mereka sendiri, kemudian guru meminta menghitung jumlah pentolan lego untuk menunjukkan bagian pembilang dan penyebut dalam materi pecahan. Permainan lego dalam tahap ini digunakan untuk mengenalkan konsep pecahan kepada siswa.

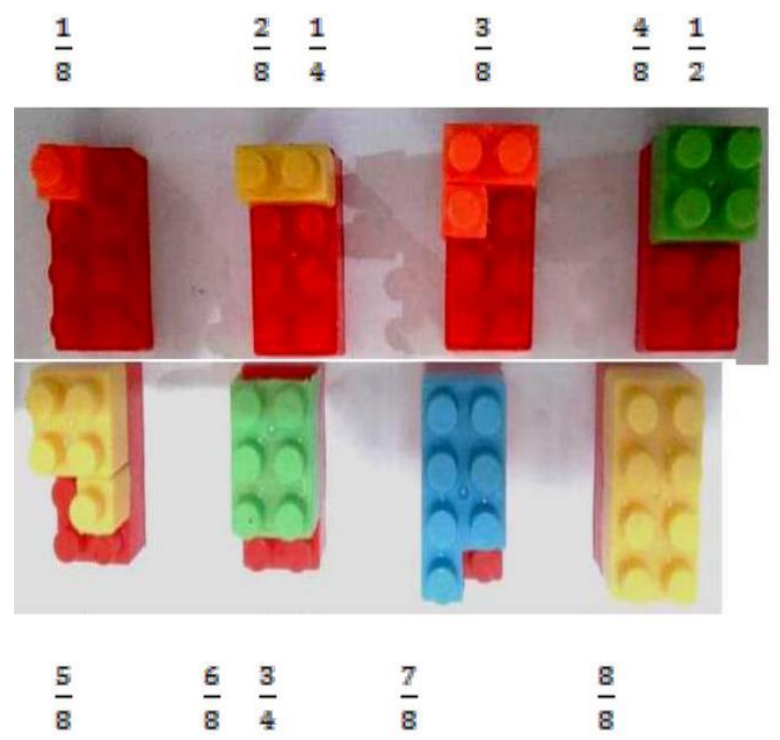

Gambar 2 Penggunaan lego untuk pecahan

Tahap kedua yaitu mengorganisasikan siswa untuk belajar. Langkah pemecahan masalah dalam tahap ini adalah menyusun rencana penyelesaian masalah. Guru memberikan pertanyaan pancingan dalam bentuk soal cerita sehingga membuat siswa merasa ingin tahu bagaimana cara penyelesaian dari masalah tersebut. Dengan bantuan lego, siswa dapat dengan mudah dalam menyusun rencana penyelesaian masalah yang diberikan guru tersebut.

Tahap ketiga yaitu melakukan penyelidikan individu dan kelompok. Langkah pemecahan masalah dalam tahap ini adalah melakukan perhitungan berdasarkan rencana penyelesaian masalah tersebut. Berdasarkan pengalaman siswa pada tahap orientasi siswa terhadap masalah dan mengorganisasikan siswa untuk belajar, siswa menjadi lebih mudah dalam proses pemecahan masalah. Siswa melakukan penyelidikan kelompok dengan menyelesaikan masalah yang terdapat dalam LKS dan bantuan permainan lego. tersusun dari lego tersebut sehingga mereka hanya mendapatkan skor 1,5. 


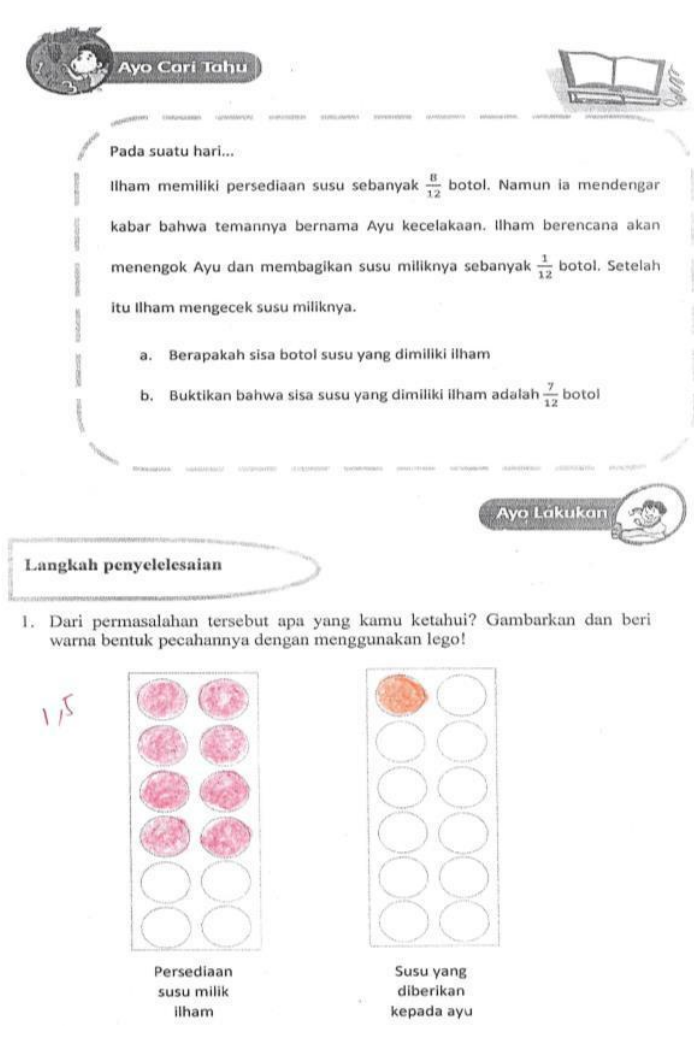

Gambar 3 Langkah pertama menyelesaikan LKS

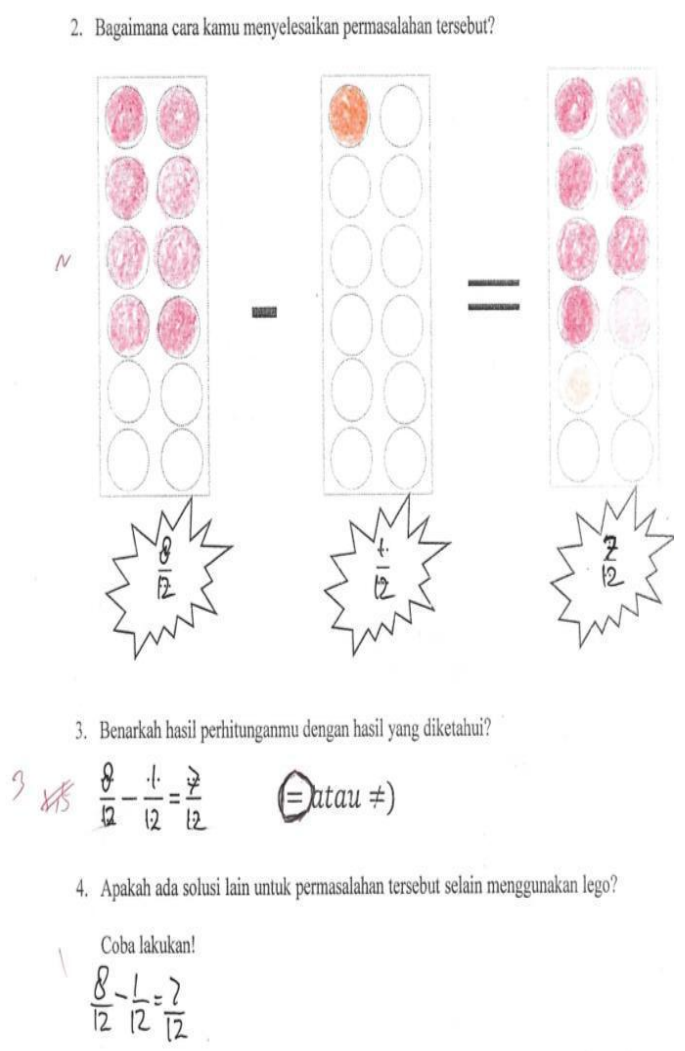

Gambar 4 Langkah pengerjaan LKS selanjutnya
Langkah kedua merencanakan penyelesaiannya dengan menggunakan lego dengan menentukan jumlah lego yang manakah yang harus dikurangkan, setelah mereka menentukan lego yang akan dikurang dengan tepat mereka berhak mendapatkan skor 2 . Langkah ketiga adalah melakukan perhitungan berdasarkan rencana yang telah mereka buat, mereka menghitung pengurangan lego yang diarsir sebagai pembilangnya karena penyebutnya sama mereka tidak perlu dikurangkan dan mereka berhasil membuktikan bahwa hasilnya sama dan berhak mendapatkan skor 3.

LKS tersebut masih belum ada peningkatan pada tahap pengecekan kembali sehingga kelompok 6 emperoleh nilai sebesar 75 . Tahap keempat yaitu menyajikan hasil diskusi. Pada tahap ini perwakilan kelompok melakukan presentasi dan kelompok lain menanggapi kelompok yang maju. Siswa yang lain dapat membandingkan hasil perhitungannya dengan hasil perhitungan kelompok yang maju apakah sama ataukah berbeda. Peran guru disini sebagai penengah jika ada siswa yang masih belum paham dengan pemecahan masalah pecahan.

Tahap kelima menganalisis dan mengevaluasi proses pemecahan masalah. Pada tahap ini guru bersama siswa melakukan tanya jawab jika masih ada siswa yang belum paham. Pada tahap ini langkah pemecahan masalah adalah mengecek kembali jawaban. Kemudian menyimpulkan pembelajaran hari tersebut. Setelah kelima tahap tersebut dilakukan setiap pertemuan, pada akhir siklus dilakukan tes evaluasi untuk mengetahui hasil dan proses pembelajaran.

Hasil rata-rata nilai tes evaluasi pemecahan masalah pada siklus 1 memperoleh 70,92 dengan ketuntasan belajar klasikal sebesar $64 \%$. Sedangkan persentase tiap indikator pemecahan masalah yaitu sebagai berikut, sebanyak 96\% siswa yang melakukan tahap memahami masalah, sebanyak $94 \%$ yang melakukan tahap menyusum rencana penyelesaian masalah, sebanyak $61 \%$ siswa yang melakukan tahap perhitungan dan sebanyak $25 \%$ siswa yang sampai pada tahap mengecek kembali jawaban.

Rendahnya kemampuan mengecek kembali hasil perhitungannya dikarenakan ketidakmampuan siswa untuk mengekspresikan jawaban dalam bentuk yang dapat diterima, hal tersebut selaras dengan Mahdayani (2016) yang mengatakan Kesalahan siswa dalam menyelesaikan soal pemecahan masalah pada tahap mengecek kembali ketika siswa mampu menyelesaikan perhitungan namun salah dalam 
menentukan jawaban akhir. Sementara itu, hasil observasi aktivitas pemecahan masalah matematika siswa memperoleh skor 2,51 dengan kriteria baik. Hasil observasi keterampilan mengajar guru siklus I memperoleh persentase 74\% dengan kriteria baik.

Berdasarkan penjelasan tersebut, dapat diketahui bahwa nilai rata-rata kemampuan pemecahan masalah matematika siswa $\geq 65$, namun belum mencapai ketuntasan belajar klasikal. Hasil observasi aktivitas siswa dalam pemecahan masalah matematika dan keterampilan guru (peneliti) dalam mengelola pembelajaran sudah memenuhi syarat indikator keberhasilan penelitian. Namun, masih terdapat beberapa kekurangan selama proses pembelajaran. Berdasarkan hasil observasi, kekurangan aktivitas siswa dan keterampilan guru pada siklus I yaitu,

1. Aktivitas pemecahan masalah pada indikator memahami masalah kurang maksimal, masih banyak siswa yang tidak percaya diri dalam menyebutkan bilangan pecahan berdasarkan susunan lego karena guru suasana kelas yang ramai.

2. Aktivitas pemecahan masalah pada indikator menyusun rencana penyelesaian, siswa masih bingung dengan konsep pecahan senilai dan siswa tidak berani mengajukan pertanyaan.

3. Aktivitas pemecahan masalah pada indikator melakukan perhitungan, siswa kurang teliti dalam mengerjakan LKS sehingga lupa membuktikan hasil perhitungan penjumlahan dan pengurangan pecahan dengan hasil yang diketahui karena guru belum bisa menjangkau seluruh kelompok dalam memberikan bimbingan.

4. Aktivitas pemecahan masalah pada indikator mengecek kembali jawaban, sebagian besar siswa melupakannya karena telah puas sudah mendapatkan jawaban.

5. Kurangnya komunikasi antar anggota kelompok sehingga pada saat menyajikan hasil diskusi ada siswa yang tidak ikut maju kedepan kelas.

Kegiatan pembelajaran siklus I dengan menerapkan model pembelajaran Problem Based Learning berbantuan permainan lego pada materi menyelesaikan masalah yang berkaitan dengan penjumlahan dan pengurangan pecahan berpenyebut sama sudah memberikan hasil yang baik pada pembelajaran matematika. Namun, kegiatan pembelajaran masih memerlukan perbaikan dari peneliti karena masih banyak kekurangan selama pelaksanaan pembelajaran. Perbaikan yang dilakukan peneliti pada siklus II yaiu.

1. Peneliti harus menciptakan suasana kelas yang lebih kondusif, agar siswa lebih memperhatikan penjelasan masalah yang disampaikan

2. Peneliti akan memotivasi siswa dengan cara memberikan nilai tambahan kepada siswa yang berani berpendapat, menanggai pendapat, bertanya ataupun menjawab pertanyaan yang diberikan guru.

3. Peneliti harus memperhatikan waktu agar dapat memberikan arahan kepada seluruh kelompok terkait langkah-langkah dalam menyelesaikan masalah yang terdapat dalam LKS.

4. Peneliti lebih memotivasi siswa agar berani maju ke depan kelas untuk melakukan penyelidikan secara individu maupun menyampaikan hasil diskusinya.

5. Peneliti lebih memperhatikan komunikasi kelompok yang tidak mau berkelompok dengan salah satu anggotanya dengan cara memberikan bimbingan dan arahan secara individu diluar jam pelajaran.

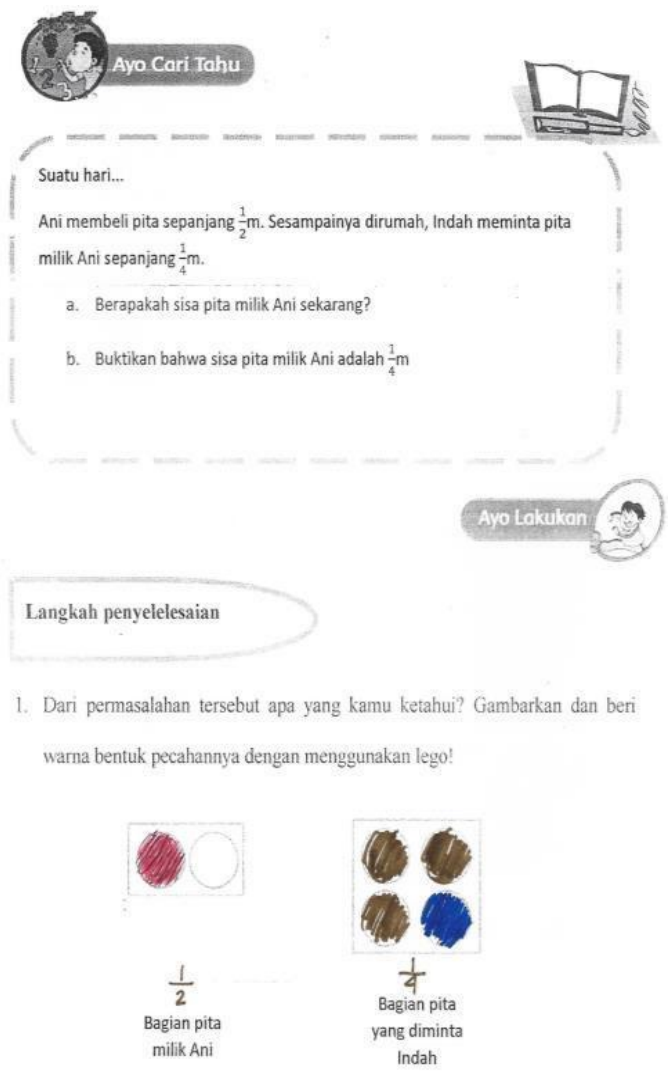

Gambar 5 Langkah pengerjaan LKS siklus II 
Kelompok 3 mengerjakan LKS dengan langkah yang dilakukan hampir sama pada pertemuan 1. Langkah mengerjakan LKS yang pertama adalah siswa memamahi masalah dengan menyebutkn apa yang diketahui dari permasalahan tersebut menggunakan bantuan lego dan mewarnai LKS berdasarkan lego yang telah disusun mereka mendapatkan skor 3.

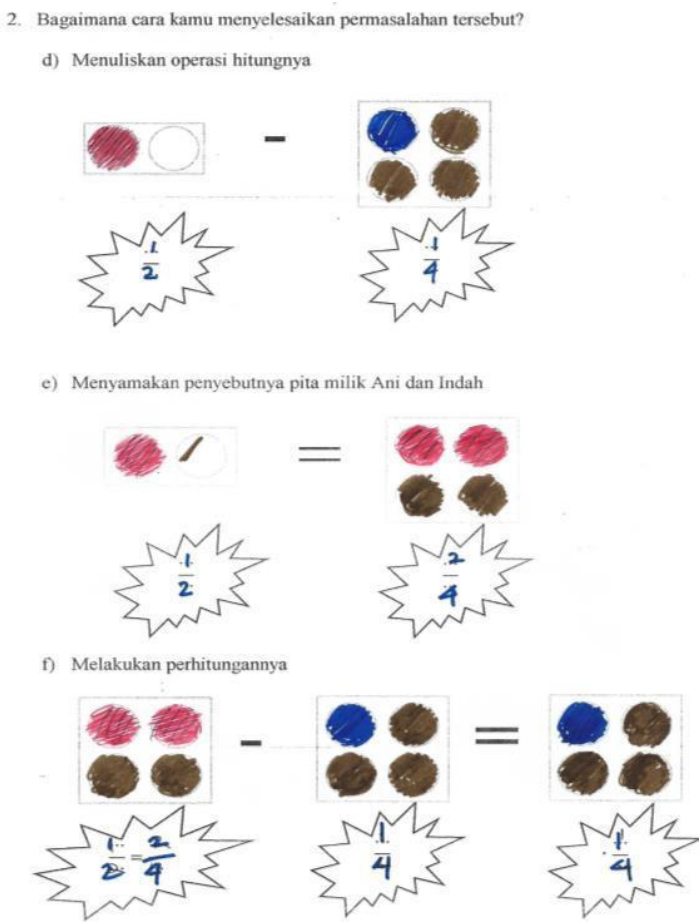

Gambar 6 Langkah Pengerjaan LKS siklus II

Langkah kedua merencanakan penyelesaiannya dengan menggunakan lego yang pertama dilakukan adalah mengubah bilangan agar mudah dihitung nantinya. Bilangan diubah menjadi pecahan senilai agar dapat dilakukan operasi hitung pengurangan pecahan berpenyebut beda. Selanjutnya menentukan lego yang manakah yang harus dikurangi/diambil, dan mereka mendapatkan skor 2 .

Langkah ketiga adalah melakukan perhitungan berdasarkan rencana yang telah mereka buat, mereka mengurangkan lego yang berwarna kuning sebagai pembilangnya karena penyebutnya sudah sama mereka tidak perlu merubahnya mereka lupa untuk membuktikan hasil perhitungannya sama dengan hasil yang diketahui atau tidak mereka hanya mendapatkan skor 1,5. Langkah keempat siswa mengecek kembali apakah jawabannya benar dengan memberikan solusi lain dalam menyelesaikan masalah mereka mendapatkan skor 2. Langkah dalam mengerjakan LKS tersebut merupakan langkah dalam proses memecahkan masalah yang berhasil mereka lakukan sehingga kelompok 3 memperoleh nilai sebesar 85 .

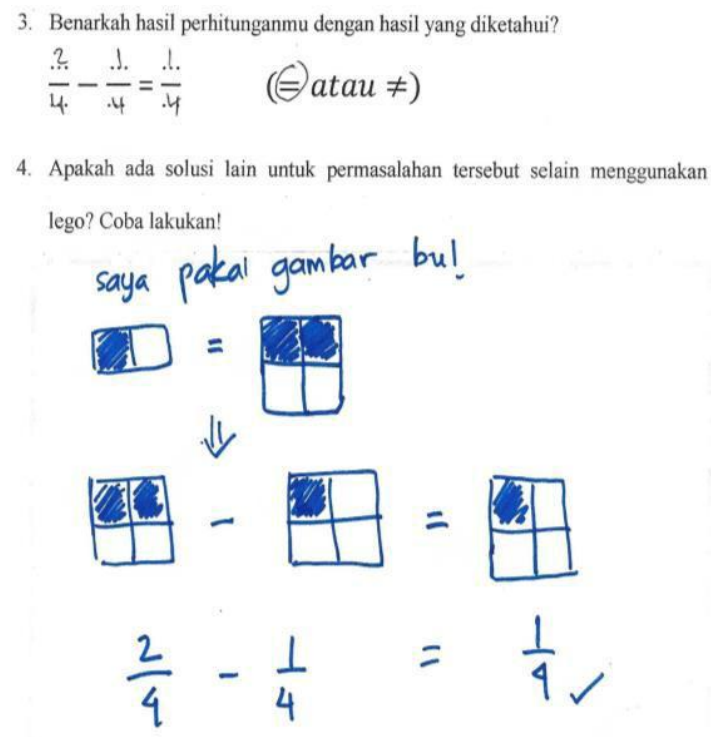

Gambar 7 Langkah Pengerjaan LKS Siklus II

Hasil pembelajaran siklus II dengan menerapkan model pembelajaran problem based learning berbantuan permainan lego materi menyelesaikan masalah yang berkaitan dengan pecahan, memperoleh nilai rata-rata 74,28 pada siklus II. Sedangkan persentase ketuntasan belajar $86 \%$ pada siklus II. Nilai rata-rata kemampuan pemecahan masalah sudah memenuhi prasyarat nilai rata-rata minimal pada indikator keberhasilan penelitian $(\geq 65)$ dan persentase ketuntasan belajar siklus II sudah memenuhi persentase ketuntasan minimal pada prasyarat indikator keberhasilan penelitian $(\geq 70 \%)$.

Jika dijabarkan tahapan dalam proses kemampuan pemecahan masalah matematika memiliki 4 tahapan disetiap soalnya yaitu memahami masalah, membuat rencana penyelesaian, melakukan perhitungan dan pengecekan kembali jawaban. Jika dianalisis lebih lanjut, pada siklus II sebanyak 97\% siswa yang mampu membuat rencana penyelesaian berdasarkan apa yang telah dipahami dalam soal. Kemudian pada siklus II sebanyak $71 \%$ siswa yang melakukan perhitungan dari perencanaannya untuk menyelesaikan masalah tersebut.

Sampai tahap yang terakhir pada siklus II sebanyak 33\% siswa yang mampu melakukan pengecekan kembali jawaban berdasarkan perhitungannya. Sementara itu, aktivitas 
pemecahan masalah matematika siswa memperoleh persentase $85 \%$ dengan kriteria sangat baik.

\section{SIMPULAN}

Berdasarkan hasil penelitian yang sudah dilaksanakan, dapat disimpulkan bahwa pelaksanaan pembelajaran matematika di kelas IV SD 1 Kedungdowo Kaliwungu Kudus tahun ajaran 2016/2017 dengan menerapkan model pembelajaran problem based learning berbantuan permainan lego telah terbukti dapat meningkatkan kemampuan pemecahan masalah matematika siswa.

Saran dalam penelitian ini, guru sebaiknya membimbing siswa secara merata agar siswa dapat memahami dan menyelesaikan proses pemecahan masalah dengan maksimal. Untuk siswa sebaiknya melaksanakan proses pemecahan masalah dengan memperhatikan langkah-langkah dengan seksama, sehingga saat dilakukan evaluasi siswa dapat melaksanakan semua langkah pemecahan masalah dengan baik.

Pihak sekolah dapat memfasilitasi guru untuk melakukan proses pembelajaran dengan menyediakan media pembelajaran yang mendukung sehingga siswa dapat memahami materi dengan mudah. Peneliti selanjutnya diharapkan dapat memberikan perlakuan khusus bagi siswa yang belum tuntas agar siswa mampu mengerjakan soal-soal kemampuan pemecahan masalah berikutnya. Sehingga proses pembelajaran dapat berlangsung dengan baik.

\section{DAFTAR PUSTAKA}

Anderson, L. W. \& Krathwohl, D. R. 2009. Pembelajaran, Pengajaran dan Asesmen. Yogyakarta: Pustaka Belajar.

Hamzah, Ali. 2014. Evaluasi Pembelajaran Matematika. Jakarta: Rajawali Press.

Heruman. 2016. Model Pembelajaran Matematika di Sekolah Dasar. Bandung: PT. Remaja Rosdakarya.

Jihad, Asep dan Abdul Haris. 2013. Evaluasi Pembelajaran. Yogyakarta: Multi Presindo.

Mahdayani, Risa. 2016. Analisis Kesulitan Belajar Siswa dalam Pemecahan Masalah Matematika pada Materi Aritmatika, Aljabar, Statistika dan Geometri. Jurnal Pendas Mahakam Pendidikan Guru Sekolah Dasar Universitas Widyagama Mahakam 1 (1) hlm 86-98.
Polya. 1973. How to solve it: A New Aspect Of Mathematical Methods. Princeton: University Press.

Rejeki, Sri, Nining Setyaningsih dan Muhammad Toyib. 2016. Optalisasi Penggunaan Lego dalam Pembelajaran Matematika SMP Untuk Mendukung Implementasi Kurikulum 2013. Warta LPM Prodi Pendidikan Matematika FKIP Universitas Muhammadiyah Surakarta 19 (2) hlm 119-124.

Runtukahu, J Tombokan dan Kandou, Selpius. 2014. Pembelajaran Matematika Dasar Bagi Anak Berkesulitan Belajar. Yogyakarta: Ar-ruzz Media.

TIMSS. 2015. TIMSS Mathematics Achievement. [online]. (http://timss2015.org/download-center/) diunduh tanggal 2 Maret 2017.

Ulya, Himatul. 2015. Hubungan Gaya Kognitif dengan Kemampuan Pemecahan Masalah Matematika Siswa. Jurnal Konseling Gusjigang 1 (2).

Wardhani, Sri, dkk. 2010. Pembelajaran Kemampuan Pemecahan Masalah Matematika Di SD. Yogyakarta: Kementerian Pendidikan Nasional Direktorat Jenderal Peningkatan Mutu Pendidik dan Tenaga Kependidikan: Pusat Pengembangan dan Pemberdayaan Pendidik dan Tenaga Kependidikan (PPPPTK) Matematika.

Warsono dan Hariyanto. 2013. Pembelajaran Aktif. Bandung: PT. Remaja Rosdakarya.

Winarni, Endang Setyo dan Sri Harmini. 2012. Matematika Untuk PGSD. Bandung: PT Remaja Rosdakarya.

Zuliana, Eka. 2015. Pengaruh Model Problem Based Learning Berbantuan Kartu Masalah terhadap Kemampuan Pemecahan Masalah Matematika Siswa Sekolah Dasar. Jurnal Refleksi Edukatika 5 